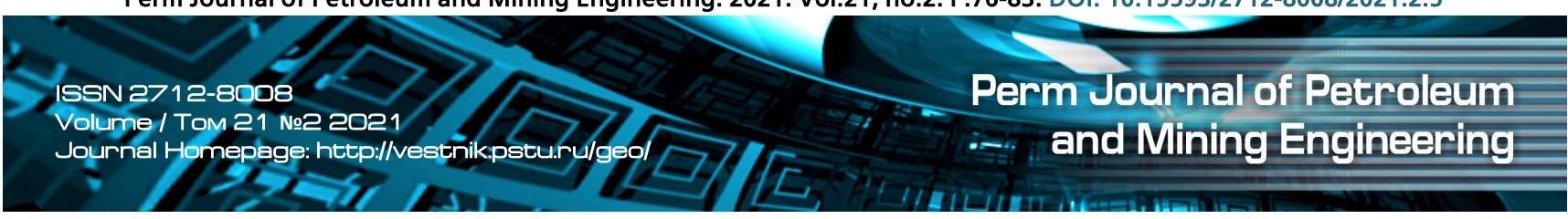

UDC 622.276

Review / Обзор

(c) PNRPU / ПНИПУ, 2021

\title{
Analysis of the Acid Compositions Application in High-Temperature Carbonate Reservoirs
}

\section{Konstantin V. Andreev}

PermNIPIneft branch of LUKOIL-Engineering LLC in Perm (3a Permskaya st., Perm, 614015, Russian Federation)

\section{Анализ применения кислотных составов в высокотемпературных карбонатных коллекторах}

\section{К.В. Андреев}

Филиал ООО «ЛУКОЙЛ-Инжиниринг» «ПермНИПИнефть» в г. Перми (Россия, 614015, г. Пермь, ул. Пермская, За)

\section{Received / Получена: 02.10.2020. Accepted / Принята: 01.02.2021. Published / Опубликована: 01.04.2021}

Keywords:

acid treatment, bottomhole zone treatment, acid treatments, carbonate reservoir, types of acid treatment, technologies, simple acid treatment, thermal acid treatment, methods of carrying out.
Ключевые слова: кислотная обработка, обработка призабойной зоны, кислотные обработки, карбонатный коллектор, виды кислотной обработки, технологии, простая кислотная обработка, термокислотная обработка, методики проведения.
The use of hydrochloric acid treatment goes back a century. For the first time, acid was applied for formation stimulation by Ohio Oil company in 1895, and the patent for acidizing limestone was obtained by Standard Oil company. However, with a significant increase in production volumes, it turned out that acid solutions caused very strong corrosion of downhole equipment. Therefore, the hydrochloric acid treatment method had not been used for 30 years. A discovery made by John Grib of Dow Chemical company in 1931 - slowing down the effect of hydrochloric acid on the metal with arsenic - made it possible to return to this method, and three years later Halliburton Oil Well Cementing began to practice acidizing on an industrial scale. As the and the of the field material has shown, there are modified acids intended for acidizing, which are characterized by a high degree of success. Nevertheless, according to the estimates of different authors, the treatment success varies in the range from 60 to $80 \%$, and for repeated treatments - less than $50 \%$.

The urgency degree of the problems associated with acid treatment of the bottomhole formation zone and the tendencies of its development were investigated. Analysis of patent information according to the International Patent Classification for 17 years (from 1997 to 2013 inclusive) for Russian patents and for 15 years (from 1999 to 2013 inclusive) - for American ones showed stable activity of Russian organizations, while foreign organizations showed a significant growth of interest and achievements in this respect.

Foreign experts mainly investigated the modeling of acid treatment [6-11], while Russian specialists were more inclined towards Foreign experts mainly investigated the modeling of acid treatment [6-11], while Russian specialists were more inclined towards
service support of acid treatment. It was revealed that there were no methods for calculating the risks of falling out of heavy oil components during acid treatment, depending on the geological and physical conditions of the target.

Использование соляно-кислотной обработки насчитывает уже вековую историю. Впервые кислоту для воздействия на пласт применила компания «Огайо Ойл» в 1895 г., а патент на кислотную обработку известняка был получен компанией «Стандарт Ойл». Однако при значительном увеличении объемов добычи выяснилось, что кислотные растворы вызывают очень сильную коррозию скважинного оборудования, поэтому метод соляно-кислотной обработки не применяли на очень сильную коррозию скважинного оборудования, поэтому метод соляно-кислотной обработки не применяли на протяжении 30 лет. Открытие Джона Гриба из компании «Дау Кемикл» в 1931 г. - замедление воздействия соляной
кислоты на металл мышьяком - позволило вновь вернуться к данному методу, и уже спустя три года компания кислоты на металл мышьяком - позволило вновь вернуться к данному методу, и уже спустя три года
«Халлибуртон Ойл Велл Сементинг» начала практиковать кислотную обработку в промышленных масштабах.

Как показал анализ промыслового материала, существует множество технологий с применением модифицированных кислот, предназначенных для кислотной обработки, характеризующихся высокой степенью успешности. Тем не менее, по оценкам разных авторов, успешность обработок изменяется в диапазоне от 60 до $80 \%$, а для повторных обработок - менее $50 \%$

Исследована степень актуальности проблем, связанных с кислотной обработкой призабойной зоны пласта, и тенденции ее развития. Анализ патентной информации по Международной патентной классификации за 17 лет (с 1997 по 2013 г. включительно) для российских патентов и за 15 лет (с 1999 по 2013 г. включительно) - для американских показал стабильную активность российских организаций, в то время как зарубежные организации проявляют в этом отношении значительный рост интересов и достижений.

Зарубежные специалисты исследуют в основном моделирование кислотной обработки, в то время как российские больше склоняются в сторону сервисного сопровождения кислотного воздействия. Выявлено отсутствие методик расчета рисков выпадения тяжелых компонентов нефти при проведении кислотной обработки в зависимости от геологофизических условий объекта воздействия.

Konstantin V. Andreev (Author ID in Scopus: 57218539507) - First Deputy Director (tel.: +007 84429677 99, e-mail: Konstantin.V.Andreev@lukoil.com).

Андреев Константин Владимирович - первый заместитель директора (тел.: +007 84429677 99, e-mail: Konstantin.V.Andreev@lukoil.com).

Please cite this article in English as:

Andreev K.V. Analysis of the Acid Compositions Application in High-Temperature Carbonate Reservoirs. Perm Journal of Petroleum and Mining Engineering, 2021, vol.21, no.2, pp.76-83. DOI: 10.15593/2712-8008/2021.2.5

Просьба ссылаться на эту статью в русскоязычных источниках следующим образом:

Андреев К.В. Анализ применения кислотных составов в высокотемпературных карбонатных коллекторах // Недропользование. - 2021. - Т.21, №2. - С.76-83. DOI: $10.15593 / 2712-8008 / 2021.2 .5$ 


\section{Introduction}

Currently, there are several modifications of acid treatment technologies. Traditionally, the following types are distinguished: hydrochloric acid bath (HAB); simple (low-volume) acid treatment; large-volume selective acid treatment (LVSAT) [1-19]; acid fracturing of formation (AFF) [20-27]; acid drilling technology [28-36]; acid treatment of closed fractures [37-43]. Additionally, acid treatment can be divided into: simple acid treatment; interval (stepwise) acid treatment [1, 13-19, 43-49]; acid treatment under pressure [14, 19]; acid treatment in dynamic mode $[49,50]$; thermal acid treatment (TAT) and thermochemical treatment (TCT) of the bottomhole formation zone (BHZ) [49, 51, 52].

Interval hydrochloric treatment or staged hydrochloric treatment are sequential treatments of several formation intervals of significant thickness (directional acid treatments).

L. Kalfayan and A. Martin in their work [19] presented various options for acid placement using flow diversion technologies, classifying the methods into the following categories:

- MAP/DIR method (maximum pressure differential and injection rate) $[14,19,43]$;

- mechanical isolation methods: blind packer or cement bridge, packer;

- combined method using a blind packer and a conventional packer;

- method of sealing balls;

- method of coiled tubing;

- methods of chemical deflection;

- protected injection by pumping the acid through the tubing, and inert liquid - through the annular space, or pumping the acid into the annular space, and inert liquid through the tubing.

\section{Methods of Hydrochloric Treatment}

The paper [47] provides an overview of field tests of various acid deflection methods using a fluid placement simulator in a formation system. Several methods can be used simultaneously to achieve the best deflection: application of coiled tubing, chemical deflection and MAP/DIR technology [48].

The injection of acid solutions into the bottomhole zone of wells under pressure allows the reagent to penetrate into the pore space of productive rocks into the depth of the formation without spending a significant fraction of acid on increasing the diameters of dissolution channels in the nearby part of the bottomhole formation zone $[14,19]$.

The highest efficiency for wells with fractured porous reservoirs is provided by high-speed high-pressure acid treatments. During treatment, microfractures are opened from the upper intervals of the net pay thickness [14].

During acid treatment, the acidic solution is injected into the formation in a traditional way in accordance with the selected technology, which determines the pressure and injection rate. When the solution enters the formation, the acid reacts with carbonates. The interaction of hydrochloric acid, especially with porous cavernous carbonate rocks, at the boundary surface between solid and liquid phases initially proceeds at a high rate. Subsequently, a surface layer of saturated rock and insoluble products is formed at the boundary surface, which significantly slows down the supply of fresh portions of acid to the reaction zone. In this case, carbonates are dissolved only due to the diffusion of hydrogen chloride molecules. The dynamic treatment mode in carbonate reservoirs, especially hightemperature reservoirs, requires continuous injection of a delayed-action acid, starting from the minimum speed and ending at the maximum permissible speed as per technological parameters of a well if there are no geological restrictions (breakthrough into water and gas saturation zones). The reaction products are extracted after a period of time conditioned upon the activity of acid under the given conditions.

If a jet pump is not available, acid treatment of the formation in the dynamic mode can be carried out using a compressor and a special valve device [50]. The developed process flow diagrams for the performance of acid treatment in a dynamic mode, as well as the results of field trials, show the effectiveness of this treatment method of the bottomhole formation zone. This specifically includes formations with high initial temperature, when the reaction rate is high (the reaction of hydrochloric acid with carbonates). The resulting products must be removed from the interaction zone as soon as possible.

The use of large-volume selective acid treatment allows to significantly increase the production rate of wells confined to carbonate reservoirs. At the same time, when interacting with carbonate rock, hydrochloric acid does not fully react with the pore space but forms large highly permeable wormholes in the rock. In this process, the skin effect can vary in the range from -2 to -5 , depending on the density of fractures, porosity, components of the acid, as well as the method and technology of its application. The impact radius of the large volume selective acid treatment exceeds $2 \mathrm{~m}$ from the wellbore (subject to radial propagation), and the acid flow rate exceeds $2 \mathrm{~m}^{3}$ per linear meter of the perforated interval. For example, with a formation thickness of $10 \mathrm{~m}$ and an acid volume starting from $20 \mathrm{~m}^{3}$, the technology can be characterized as large volume selective acid treatment. Fractured reservoirs require a multiple (3-6 times) increase in the volume of acid [13].

The main conditions for the effectiveness of the large volume selective acid treatment are [13]: consideration of the criteria for the acid treatment application when selecting the priority well candidates; design: comparison of laboratory and field studies; determination of changes in well production rates during well flow tests; process modeling and design optimization; filtration process control: interlayer processing; the use of an acid composition with process slowdown - oil-acid emulsions (OAE), acid-containing polymer compositions gelled inside the formation, self-diverting acid compositions (SDAC); compliance with the optimal processing design.

When designing acid stimulation, the geological and physical characteristics of the reservoir should be taken into account: its mineralogical composition, permeability, compressibility and porosity of rock, fluid viscosity and temperature. Logging results, petrophysics and field development indicators should be taken into account to better understand the problems associated with the deterioration of the porosity and permeability characteristics of the reservoir rock. Subsequent analysis is related to the study of the history of selected wells with further determination of actual parameters and overall efficiency of the acid treatment. Core studies, including the study of pore space structure, filtration-capacity properties and contact angle of wettability, compatibility of rock with the well-killing solution and other process fluids planned for use, and other studies make it possible to validate the acid composition for well treatment. The use of experimental data in the field should be carried out with certain assumptions, since with the growth of lithological and structural changes the justification for the acid 
optimization and the design of its application acquire a significant role. When producing highly conductive wormholes during acid treatment, the most important aspects are the control processes related to filtration, injection rate, and rate of reaction with rock. The control of filtration processes makes it possible to increase the success of acid treatment in fractured-porous reservoirs and to achieve high recovery from all oil-saturated intervals of the formation [14]. The standard acid treatment uses either ordinary hydrochloric acid or that modified with retarders $[16,17]$ together with diverting reagents [18, 53, 54]. An isolating compound (diverter) blocks the water-saturated / high-permeability formation intervals, making the acid to enter the low-permeability / oil-saturated parts of the formation. When modeling acid action, the acid solution volume estimation is carried out separately for each well of a particular field. This task presents significant challenges due to the dependence of acid volumes on numerous factors related to reservoir geology, development processes, and process technology. In addition, it is necessary to take into account the heterogeneity of the bridging zone when the fracture crosses the damaged part of the bottomhole zone. A distinctive feature of the technical organization of large volume selective acid treatment is the need to mobilize a sufficient amount of equipment and tanks at a well cluster in order to accumulate a large amount of acid to ensure the continuous treatment process. The treatment shall only start after all the necessary components are available on site. As noted earlier, the large volume selective acid treatment has a significant success when it is carried out in carbonate deposits with natural or acquired fracturing. The process efficiency is low in low-permeability carbonate reservoirs. Nevertheless, good results can be achieved when performing acid fracturing of formation, i.e. in a joint process involving hydraulic fracturing and direct acid treatment of carbonate rock. Acid fracturing of formation is performed in carbonate reservoirs with low permeability in order to increase their conductivity due to the creation of fractures and increase the treatment depth along the productive formation direction. Acid fracturing of formation performed during the injection of fluids at pressures higher than the rock fracture pressure is aimed at the creation of a highly conductive channel by inhomogeneous dissolution of the fracture walls. In order to achieve high efficiency of acid fracturing, it is necessary to ensure that the channels remain open after exposure to acid. After the acid action in a fracture, the carbonate rock dissolves faster in comparison with other minerals; when the fracture is closed, undissolved carbonates create an obstacle to their closure. The void space in the formed channels creates the so-called fracture conduction channels, thereby ensuring the flow of oil to a well, including a high-rate one. In soft carbonates, the maintenance of fracture conductivity due to newly formed channels may not be achieved, since the process of fracture collapse may occur during subsequent development. Taking into account the above arguments, as a rule, acid fracturing with fracture reinforcement by proppant is used for the reservoirs in question [55]. The proppant volume can be increased up to $30 \%$ depending on the rock nature. An important role in the acid compound is played by corrosion inhibitors and additives, which are functionally aimed at reducing acid loss through the fracture walls, justified by minimization of secondary clogging in the bottomhole formation zone. The immediate fracture size is determined by the rate of reaction of the acid with rock and depends on the amount of acid leakage into the fracture walls. A gel rim is used to create conditions for the long fracture formation, but acid injection at the subsequent stage may have significant leaks through the fracture walls, as a result of which the depth of the acid penetration into the fracture decreases, which in turn leads to a decreased effect [20]. It is noticed that the fracture length depends on the formation temperature. Moreover, a decrease in the low-permeability formation temperature leads to an increase in its length. For the considered purposes, the additives are used during acid fracturing which reduce fluid leakage through the fracture walls. There is considerable world experience of the successful application of acid fracturing, several monographs exist considering this method [21-26], among which one should pay attention to the constantly updated work of one of the leading experts in the field of well stimulation, Michael Economides. It is necessary to mention the published [27] positive experience of acid fracturing at the Devonian site of the Kharyaginskoye field of the Timan-Pechora oil and gas province. The standard fracture treatment method generally gives good results in carbonate reservoirs. The acid front passes through the open fracture and dissolves the fracture surface unevenly so that the structure of the formed channels becomes extended. But often these channels, opened under pressure during treatment, reduce after treatment, and the fracture closes [50]. In 1970, much attention was paid to the opening of natural fractures and their consolidation in the work of G.T. Ovnatanov [37], where he noted the successful acid treatment of naturally fractured reservoirs, including the south of the Siberian platform. He studied the Osinsky horizon of the Atovskaya, Balykhtinskaya and other areas, as well as a number of sites at other fields. The positive experience of the microfractures deep propping technology by corundum with sand in well No. 4 of the Chaladidi field was provided. Depending on the general geological conditions and, mainly, on the fracture network which cut through the rock in a given section, the treatment process is carried out in two technological options [37].

Option 1. The network of microfractures is evenly distributed throughout the reservoir and in the vicinity of the production bottomhole. Under such conditions, natural microfractures are propped by a working fluid within a radius of $1 \mathrm{~m}$ from the well walls, and acid dissolves the minerals that fill the fractures. After keeping the acid mixture in the formation under pressure, it is then removed from the formation by drainage. When the acidity in the incoming liquid samples sharply decreases and gradually disappears, the second stage of the procedure is started, namely, the fractures are consolidated with a solid agent. Having placed a solid agent in the fracture, the well is left alone for some time, after which the walls of the fractures become closer, and only after that it is possible to start well tests. The opening of fractures in this position will be kept in the formation for a long time by a stopper made of a mixture of high-strength grinding grains of heavy corundum and quartz sand, transported along the wellbore and placed in the fracture by a viscous carrier fluid. The process is also planned for cases where the well production bottom is composed of rocks, dissected by open microfractures and filled with parent oil (natural gas), but which closed during opening. In order to restore the initial microfractures throughput, it is necessary to open and fix them with a solid agent at a distance of no more than $1 \mathrm{~m}$ from the walls, but according to a simplified process without intermediate work on the formation acid treatment.

Option 2. The network of natural microfractures, which cut through the rock in the well production bottom zone, is located at some distance from the main 
direction of their development, and microfractures are not intersected by the well. The conclusion on the possibility to dissect the rock mass by microfractures in this way can be drawn based on numerous facts that are often encountered in the oil and gas exploration practice (Osinsky horizon, Eastern Siberia) [37]. In such acid fracturing operations, the main type of rock destruction increasing its permeability is no longer a continuous increase in the size of the open section of fractures but the creation and development of communication channels that go deep into the formation where the acid corrodes the rock of microfracture walls and dissolves mineral formations filling microfractures at a great distance from the production bottomhole. In this case, obviously, the acid solution must be directed along the path until it meets the main direction of the natural microfractures development; however, obviously, it should flow not along several channels, but along one or two channels of significant length. Consequently, a distinctive feature of this process is that the working fluid reaches the zone of the formation with highfrequency fracturing, as a result of which the well establishes stable connection with the feed source [37]. Closed fracture acid treatment has been also developed in foreign works. It has been shown that previously fractured wells can be retreated using a closed fracture acid injection system at a pressure lower than the pressure required to open the fracture. This method is called CFA technology (closed fracture acidizing) [3842]. This closed fracture acid injection process can be considered for any carbonate formation that is already fractured, as the acid "selects" higher conductivity channels. This is especially important for lowpermeability reservoirs. These fractures can be of the following origin [38]: 1) fractures created immediately before the treatment of a closed fracture; 2) fractures created earlier as a result of acid injection into the fracture or hydraulic fracturing; 3) natural fractures. Fig. 1 shows a three-dimensional image obtained from a set of two-dimensional images of a tomographic scanner, the result of acid penetration into a perforation. It can be seen that the acid penetrates into the low-porosity matrix only little, if at all, but propagates along the perforation (cavity analogue) and fracture. The wormholes form only after this [56].

The closed fracture acid injection method is designed to allow acid to flow through the existing closed fractures at a pressure below the fracture pressure by channeling. As the acid is pumped at a slow rate and dissolves large flow channels, wide grooves or channels are formed on the fracture surface. These grooves tend to remain open while maintaining good conductivity under severe closure conditions, and they also let fine particles or emulsions to be easily discharged. Besides, the original fracture system can be represented by natural fractures created by a hydraulic fracturing operation, or fractures created and etched just prior to "closed" treatment. The method is based on injecting acid through a closed or partially closed fracture at the fracture opening pressure or a little below it, to prevent the fracture from opening to a noticeable width. Acid flows out of this closed fracture, possibly in a turbulent flow, rapidly dissolving a bigger part of the rock surface than in case of the open fracture flow. In addition, most carbonate reservoirs have areas or mineral veins that have different reaction rates mainly due to different solubility in hydrochloric acid, rock composition or permeability. This condition usually allows one area to dissolve faster than adjacent areas. Areas or veins of rock that are dissolved by acid at a faster rate become larger, and in a very short time most of the acid tends to flow

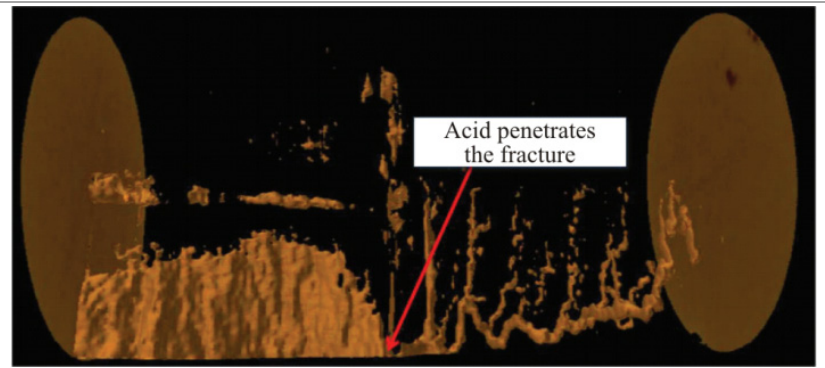

Fig. 1. Limestone sample after hydrochloric treatment

through them, thereby creating channels or grooves. Under certain conditions, these channels become so large that theacid is no longer in the turbulent flow. These freely soluble areas of the reservoir are distributed according to the bedding plane [37], if any, which is mostly horizontal. This tends to cause the acid to flow radially rather than vertically.

Once the acid has dissolved a small portion of the fracture surface, creating relatively deep channels or grooves, the remaining fracture surface can keep the channel open under high rock pressure without completely destroying the etch channel. In the work [57], a comparison of various designs of the combination of this technology with the acid fracturing technology is made for the LN field in the Taryn province of China with different directions of fractures of the Ordovician formation. It is also important to note the disadvantages of the CFA method, which must be taken into account: 1) a method of modeling or predicting the number or the length of etched channels has not been developed for this technology; 2) deflection with balls can be a problem at low injection rates and differential pressure across perforations; however, this problem can be usually solved by using low weight or balanced density seal balls and/or by increasing the pumping rate when the seal balls are at the perforations. An alternative is the interval treatment. Closed fracture acid injection will not work in certain types of carbonate formations, and they are difficult to identify and predict, unless core filtration studies have been performed. So, when the formation has several zones that cannot be drained vertically, each zone needs to be treated. If some perforation intervals are associated with a system of natural fractures, while others are not, then flow deviation at a pressure sufficient to fracture unconnected interlayers is a difficult task. The literature review of closed fracture treatment shows mixed success of treatments. It was found that in order to achieve efficiency in closed fracture treatment for low-permeability formations it is required to increase the fracture length, while a fracture conductivity increase is important for permeable reservoirs [58]. Wells with good initial permeability are also the best candidates for treatments [59]. D.I. Parrot and M. G. Long [60] examined both successful and unsuccessful re-opening treatments in a low-permeability gas reservoir and concluded that wells with good initial productivity are the best candidates for fractures re-opening. Distinctive features of fractured reservoir behavior are formulated in works [37, 61]. During the treatment of a formation with a fractured reservoir, the fracture opening pressure is determined, but not the injectivity as for a porous reservoir. In a fractured reservoir, the fracture opening pressure is important primarily because there is practically no injectivity in the formation until the pressure is achieved. At the very beginning, when elastic properties of the formation begin to manifest, the fluid is injected at very low flow rates. A further increase in the injection pressure leads to a new 
qualitative state of the bottomhole formation zone permeability - natural fractures begin to open: the pressure no longer grows, but begins to fall abruptly, accompanied by an increasing volume of working fluid injected into the formation [37]. Where there is no natural fracturing of the formation on the wellbore wall contour or near it, the working fluid will not enter the formation until the hydraulic fracturing pressure is achieved.

\section{Selection of Reagents}

After determining the technology option, it is necessary to select reagents containing an acidic component. It can be the acid itself with various additives or an acid-generating mixture of substances that releases acid in the formation that reacts with a bridging agent or reservoir formation rock. Since carbonate reservoirs, by their chemical nature, are salts of carbonic acid which are freely soluble in acids, acid stimulation is the main method of well stimulation in carbonate reservoirs. The basic reagent used to restore or increase the permeability of the bottomhole zone of wells in carbonate reservoirs is hydrochloric acid ( $\mathrm{HCl})$; acetic acid $\left(\mathrm{CH}_{3} \mathrm{COOH}\right)$, aminosulfonic acid $\left(\mathrm{NH}_{2} \mathrm{SO}_{3} \mathrm{H}\right)$ are also used. In addition, in order to slow down the reaction of rock with acid, reagents that generate acids in the formation (salts of nitric and phosphoric acids, esters of organic acids) as well as non-acid reagents (chelates) - N, N-bis- (carboxymethyl) - L-glutamic acid and its salts, ethylenediaminetetraacetic acid (EDTA), oxyethylidene diphosphonic acid (OEDP), nitrilotrimethylphosphonic acid (NTF) dissolving carbonate rock at high temperatures $[62,63]$ are used instead of $\mathrm{HCl}$. The overwhelming majority of well stimulation methods in carbonate reservoirs are based on the creation of highly conductive channels $[12,20,23,56,64-68]$. Depending on the type of treatment and the pore space structure, these can be either fractures or wormholes (Fig. 2).

It should be noted that an increase in the injection rate leads to the formation of more branched wormholes and is consistent with the experimental and theoretical results of several researchers [69].

The acid treatment of carbonates is usually carried out using $\mathrm{HCl}$, where it reacts according to the equations:

- with limestone: $\mathrm{CaCO}_{3}+2 \mathrm{HCl} \rightarrow \mathrm{CaCl}_{2}+\mathrm{CO}_{2} \uparrow+\mathrm{H}_{2} \mathrm{O}$;

- with dolomite: $\mathrm{CaMg}\left(\mathrm{CO}_{3}\right)_{2}+4 \mathrm{HCl} \rightarrow \mathrm{CaCl}_{2}+\mathrm{MgCl}_{2}+$ $+2 \mathrm{CO}_{2} \uparrow+2 \mathrm{H}_{2} \mathrm{O}$

Calcium chloride and magnesium chloride resulting from the reaction are freely soluble in water. Carbon dioxide is also easily removed from the well or, at the appropriate pressure (over $7.6 \mathrm{MPa}$ ), dissolves in water [52] as well. A 10-15\% solution of hydrochloric acid is usually prepared for well treatment, since with its higher content the neutralized solution turns out to be very viscous, which makes it difficult to exit the formation pores. However, for low-temperature dolomite deposits, the concentration of hydrochloric acid can be increased up to $20-24 \%$, since dolomites require higher specific consumption of acid, and their dissolution rate is significantly lower than that of limestones. Let us consider the most famous modifiers used in acid compositions for various purposes. Thus, acid corrosion inhibitors are used to reduce acid corrosion of well equipment. They are adsorbed on the surface of pipes, forming a protective film that reduces the rate of acid attack on steel. Acid corrosion increases with increasing temperature, and the inhibitor's ability to adsorb on steel decreases. The use of two inhibitors together has a synergistic effect on corrosion reduction. The main factors influencing corrosion are the nature of steel itself,

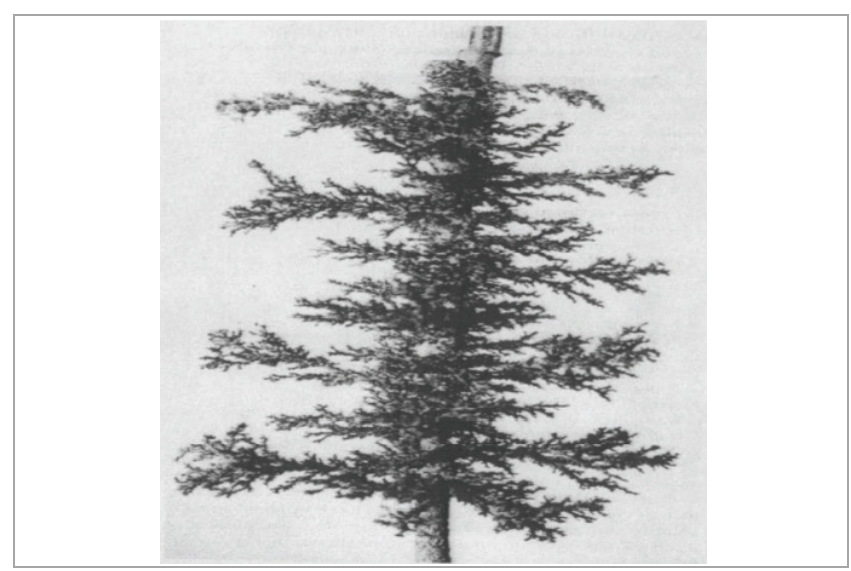

Fig. 2. Channels in the carbonate samples after hydrochloric treatment

the type of acid, its concentration, stirring, temperature, pressure, solubility of acid corrosion inhibitor and its concentration, the ratio of the metal area to the acid volume, contact time, the presence of a synergistic effect during inhibition, the effect of other additives.

In 1935-1936, the USSR started to use formalin as an inhibitor of acid corrosion [49]. Surfactants are also used in the acid treatment to reduce the rate of reaction with rock, promote foaming, demulsify water-in-oil emulsions (WOE), lower capillary pressures in a porous medium, improve the solubility of oil-saturated reservoirs, reduce hydraulic losses due to friction (Toms effect), break and wash asphaltene-resin-paraffin deposits (ARPD), invert the reservoir surface wettability $[23,65]$.

The number of surfactants used depends on the purpose of their use. Surfactants used to reduce phase tension and/or hydrophilization are usually used in an amount of 0.2 to $0.5 \%$. Other targets require higher concentrations. Mutual solvents are a group of polar nonelectrolytes that dissolve in oil, acid, fresh water, and mineralized water. In the literature, mutual solvents are also called universal solvents [12]. Mutual solvents penetrate deeper than surfactants and are used to increase the miscibility of acid and oil by reducing boundary or surface tension. They are more effective than most surfactants as surface hydrophilizers for prevention of emulsification and minimization of sludge formation (setting of heavy oil components). In addition, mutual solvents dissolve oil in the pore space of the formation, making the pore surface hydrophilic. Thus, mutual solvents allow to control the rate of reaction of the acid with rock. The end result is that mutual solvents improve post-treatment waste acid recovery. The concentration of mutual solvents depends on the purpose and conditions of use, but ranges from 0.5 to $35.0 \%$. Incompatibility occurs when mixing different surfactants and/or mutual solvents. Aliphatic alcohols, carboxylic acids, acetone, dioxane, esters of alcohols and organic acids, ethers of alcohols and glycols (cellosolves) can be used as mutual solvents. Methanol, acetone, isopropanol, butanol, including bottoms, glycols (polyglycols), dioxane alcohol derivatives [12] are the main nonhydrocarbon solvents for the acid treatment of bottomhole formation zone the in Russian fields.

In foreign practice of oil and gas production, preference is given to solvents of the mutual solvent class, with their differentiated action in the bottomhole formation zone pursued. Ethylene glycol monobutyl ether (EGMBE, butyl cellosolve) is the most frequently studied and widely used reagent in the acid composition in the US fields [12, 23]. The concentration at which EHMBE is used varies from 1 to 
$10 \%$, but the optimal concentration is considered to be 3-5\% [23]. It should also be noted that polar solvents are used not only as modifiers of the acid composition, but also as an independent stage carried out before the acid injection. Aromatic solvents are mainly used for this purpose [4]. Additives, so-called clay stabilizers, are substances used to minimize the absorption of water by the aluminosilicate particles. The use of additives for aluminosilicates prevents clogging, emulsion formation, and reduces the treatment pressure and the time for cleaning the bottomhole formation zone. Traditionally, ammonium or potassium chlorides are used as clay stabilizers, but these reagents are mainly used as a pre-rim before the acid injection. Quaternary amines and quaternary polyamines are also used as stabilizers [4, 23]. In addition, for this purpose, hydrofluoric acid in the composition of mud acid can be replaced by hydrofluoric acid to eliminate secondary clogging with clay particles [4]. In order to deliver acid to the required formation intervals and increase the depth of acid penetration into the formation, various modifications of acid compositions are used. These are oil-acid emulsions, foam acids, gelled acid systems, and self-diverting acid systems. It is known that the viscosity and stability of oilacid emulsions depend on many factors, such as the method of preparing the emulsion, oil characteristics, the ratio of the amount of acid to oil, emulsifier, etc. [49].

The action of polymer-based chemical diverters [48] is associated with blocking of highly conductive channels of the formation in order to further stimulate the entire bottomhole formation zone [48]. Recently, in the foreign literature, there have been reports on new acid treatment technologies of productive formations. The acid treatments with preliminary injection of carbon dioxide and with the use of viscoelastic self-diverting acid compositions represent the greatest interest, in particular, the Schlumberger technology, VDA (viscoelastic diverting acids), which is a mixture of acid and a micelle-forming surfactant. The VDA operation principle is based on the change in its rheological properties depending on the acidity of the medium. While the VDA system (a mixture of $\mathrm{HCl}$, viscoelastic surfactant that is a molecule with a positive quaternary ammonium and negative carboxyl group head and a long hydrophobic hydrocarbon tail, and conventional additives required for acid treatment) is pumped down the wellbore through tubing or casing, it retains low viscosity, then thickens, blocking the channels, and finally, when the acid concentration approaches depletion, it liquefies again [70].

The unique rheological properties of the VDA system allow to increase injection rates when using coiled tubing strings, and at the same time provide exceptional diverting capabilities that are required for absorber solution injection under more challenging well completion conditions [52].

\section{Conclusion}

Various technologies for acid treatment of carbonate fields have been studied. The lack of a uniform approach to the selection of criteria for the technologies applicability depending on the geological and physical conditions of productive reservoirs has been shown. Analysis of the technology for retarding acid compositions for the conditions of high-temperature carbonate reservoirs has shown good perspectives of using acid compositions retarded by surfactants, organic acids, and chelates. The analysis of technologies for preventing clogging of the bottomhole formation zone, which occurs during acid treatments, has been carried out. The absence of methods for calculating the risks of heavy oil components settlement during acid treatment, depending on the geological and physical conditions of the field, has been provided.

\section{References}

1. Kroui K., Masmonteil Zh., Toubul E., Ron T. Tendentsii v obrabotke matritsy [Matrix Processing Trends]. Neftianoe obozrenie, 1996, no. 10, pp. 20-37.

2. Grei F. Dobycha nefti [Oil production]. Moscow: Olimp-Biznes, 2001, 416 p.

3. Fransh H. Increasing the Flow of Oil Wells. US 556669, 1896.

4. Rae Ph., di Lullo G. Matrix Acid Stimulation. SPE European Formation Damage Conference The Hague, The Netherlands, 13-14 May, 2003. Paper SPE 82260, 2003. DOI: 10.2118/82260-MS 5. Telin A.G., Ismagilov T.A., Akhmetov N.Z., Smykov V.V., Khisamutdinov N.I. Kompleksnyi podkhod k uvelicheniiu effektivnosti kislotnykh obrabotok skvazhin v karbonatnykh kollektorakh [An integrated approach to increasing the efficiency of acidizing wells in carbonate reservoirs]. Neftianoe khoziaistvo, 2001, no. 8, pp. 69-74.

6. Tardy Philippe. Method for Predicting Acid Placement in Carbonate Reservoirs. Patent U.S. no. 7603261 (2009).

7. Tardy Philippe, Lecerf Bruno. Flow of Self-Diverting Acids in Carbonate Reservoirs. Patent U.S. no. 7774183 (2010).

8. Cohen Charles Edouard, Ding Didier, Bazin Brigitte, Quintard Nichel. Method for Large-Scale Modeling and Simulation of Carbonate Wells Stimulation. Patent U.S. no. 7853440 (2010).

9. Fu Diankui. Self-Diverting Pre-Flush Acid for Sandstone. Patent U.S. no. 7666821 (2010),

10. Fu Diankui, Panga Mohan, Kefi Slaheddine, Marieliz Garcia-Lopez de Victoria. Self Diverting Matrix Acid. Patent U.S. no. 7770644 (2010).

11. Syed Ali, Javier Sanchez Reyes, Mathew M. Samuel, Francois M. Auzerais. Self-Diverting Acid Treatment with Formic-Acid-Free Corrosion Inhibitor. Patent U.S. no. 7902124 (2011). 12. Glushchenko V.N., Ptashko O.A., Kharisov R.Ia. Kislotnye obrabotki: sostavy, mekhanizmy reaktsii, dizain [Acid treatments: compositions, reaction mechanisms, design]. Ufa: AN RB, Gilem, 2010, 388 p.

13. Kharisov R.Ia., Sharifullin A.R., Telin A.G., Zagurenko A.G. Faktory, vliiaiushchie na effektivnost' kislotnoi stimuliatsii skvazhin v karbonatnykh kollektorakh [Factors affecting the effectiveness of acid stimulation of wells in carbonate reservoirs]. Nauchno-tekhnicheskii vestnik OAO "NK "Rosneft"', 2007, no. 1, pp. 18-24.

14. Pongratz R., Kontarev R., Robertson B. Optimizing Matrix Acid Treatments in a Multilayered Reservoir in Russia by Applying Different Diversion Techniques. SPE 94485, 2005, May, 27. DOI: 10.2118/94485-MS

15. Vakhrushev S.A., Folomeev A.E., Kotenev Iu.A., Nabiullin R.M. Issledovaniia kislotnogo vozdeistviia s primeneniem potokootklonitelei na karbonatnye kollektory mestorozhdeniia imeni R. Trebsa [Acid treatment with diverting on carbonate reservoirs of R. Trebs oil field]. Neftianoe khoziaistvo, 2016, no. 4, pp. 112-117.

16. Navarrete R.C., Holms B.A., McConnell S.B., Linton D.E. Emulsified Acid Enhances Well Production in HighTemperature Carbonate Formations. SPE 50612, 1998, October, 20-22. DOI: 10.2118/50612-MS

17. Nasr-El-Din H.A., Solares J.R., Al-Mutairi S.H., Mahoney M.D. Field Application of Emulsified Acid-Based System to Stimulate Deep, Sour Gas Reservoirs in Saudi Arabia. SPE 71693, 2001, September, 30-October, 03. DOI: 10.2118/71693-MS

18. Saxon A., Chariag B., Reda Abdel Rahman M. An Effective Matrix Diversion Technique for Carbonate Formations. SPE 37734, 1997, March, 15-18. DOI: 10.2118/37734-MS 19. Kalfayan L.J., Martin A.N. The Art and Practice of Acid Placement and Diversion: History, Present State, and Future, SPE 124141, 2009. DOI: 10.2118/124141-MS

20. Gdanski R. Recent Advances in Carbonate Stimulation, IPTC 10693, 2005, November, 21-23. DOI: 10.2523/IPTC-10693-MS

21. Williams B.B., Gidley J.L., Schechter R.S. Acidizing Fundamentals. Soc. Petrol. Eng. of AIME. New York, Dallas, 1979, Ch. 10.

22. Economides M.J., Nolte K.G. Acid Fracture Propagation and Production, in Reservoir Stimulation. Prentice Hall, Englewood Cliffs, NJ, 1989 , Ch. 18.

23. Economides M.J., Nolte K.G. Reservoir Stimulation. 3 Ed. John Willey \& Sons, Ltd, New York, 2000

24. Ekonomides M., Nolte K. Povyshenie produktivnosti neftegazovykh kollektorov [Increasing the productivity of oil and gas reservoirs]. Moscow.-Izhevsk: Institut komp'iuternykh issledovanii, 2011, vol. 1, 676 p., vol. 2, 674 p.

25. Economides M.J., Hill A.D., Ehlig-Economides C. Petroleum Production Systems. Upper Saddle River, NJ 07458, 1993,611 p.

26. Ekonomides M., Olini R., Val'ko P. Unifitsirovannyi dizain gidrorazryva plasta: ot teorii k praktike [Unified Fracturing Design: From Theory to Practice]. MoscowIzhevsk: Institut komp'iuternykh issledovanii, 2007, 236 p.

27. Puatreno A., Ferran P., Puzhet P., Men'er Zh. Uspeshnyi kislotnyi gidrorazryv plasta (GRP) v neblagopriiatnykh usloviiakh Khar'iaginskogo mestorozhdeniia: poluchennyi opyt i kompleksnaia otsenka rabot [Successful Acid-Fracturing in Adverse Conditions: Lessons Learnt and Integrated Evaluation in the Kharyaga Field]. SPE 102475, 2006. DOI: 10.2118/102475-MS

28. Rae Philip J., Di Lullo Arias, Gino F., Portman, Lance N. Chemically Enhanced Drilling Methods. Patent U.S. no. 6772847 (2004).

29. Rae Ph., di Lullo G. Chemically-Enhanced Drilling With Coiled Tubing in Carbonate Reservoirs. SPE 67830. DOI: 10.2118/67830-MS

30. Portman L., Rae Ph., Munir A. Full-Scale Tests Prove it Practical to "Drill" Holes with Coiled Tubing Using Only Acid; No Motors, No Bits. SPE 74824, 2002. DOI: $10.2118 / 74824-M S$ 
31. Stanley F.O., Portman L.N., Diaz J.D., Darmawan R.L., Strasburg J.P., Clark J.S., Navarro M.S. Global Application of Coiled-Tubing Acid Tunneling Yields Effective Carbonate Stimulation. SPE 135604, 2010. DOI: 10.2118/135604-MS

32. Moss P., Portman Rae L., di Lullo G. Nature Had It Right After All! Constructing a "Plant Root" - Like Drainage System with Multiple Branches and Uninhibited Communication with Pores and Natural Fractures. SPE 103333, 2006. DOI: 10.2118/103333-MS

33. Perex L.A.A., Diaz J.D., Navarro M., Moss P., Curtis J. Successful Offshore Application of Acid Tunneling Technology: Overcoming the Difficulties of High Depths, Temperatures, and Deviations. SPE 113855, 2008. DOI: 10.2118/113855-MS

34. Diaz J.D., Espina V., Guerrero M., Colmenares O., Moss P. Successful Implementation of Coiled-Tubing Acid Tunneling Gives Operator a Viable Alternative to Conventional Stimulation Techniques in Carbonate Reservoirs. SPE 107084, 2007. DOI: 10.2118/107084-MS

35. Akhkubekov A.E., Vasilyev V.N. Acid Tunneling Technology: Application Potential in Timan-Pechora Carbonates. SPE 135989, 2010. DOI: 10.2118/135989-MS

36. Strasburg J., Clark J. Acid Tunneling Stimulation in Oklahoma Limestone Using Coiled Tubing. SPE 120772, 2009. DOI: 10.2118/120772-MS

37. Ovnatanov G.T. Vskrytie i obrabotka plasta [Opening and treatment of the formation]. Moscow: Nedra, 1970, $312 \mathrm{p}$.

38. Fredrickson S.E. Stimulating Carbonate Formations Using a Closed Fracture Acidizing Technique. SPE 14654, 1986. DOI: 10.2118/14654-MS

39. Frederickson S.E., Knox J.A. Method of Fracture Acidizing Formation. Patent U.S. no. 3768564 (1973).

40. Knox J.A., Frederickson S.E. Method of Fracture Acidizing a Well Formation. Patent U.S. no 3842911 (1974).

41. Sollman M.Y., Hunt J.L., Daneshi T. Well-Test Analysis Following a Closed-Fracture Acidizing Treatment. SPE 17972, 1990. DOI: 10.2118/17972-PA

42. Bartko K.M., Conway M.W., Krawietz T.E., Marquez R.B., Oba R.G.M. Field and Laboratory Experience in Closed Fracture Acidizing the Lisburne Field, Prudhoe Bay, Alaska. SPE 24855, 1992. DOI: 10.2118/24855-MS

43. Paccaloni G., Tambini M. Advances in Matrix Stimulation Technology. JPT, 1993, no. 43(3), pp. 256-263. DOI: 10.2118/20623-PA

44. Bhalla K. Coiled Tubing Extended Reach Technology. SPE 30404, 1995. DOI: 10.2118/30404-MS

45. Nasr-El-Din H.A., Al-Habib N.S., Jemmali M., Lahmadi A., Samuel M. A Novel Technique to Acidize Horizontal Wells with Extended Reach. SPE $90385,2004$. DOI: $10.2118 / 90385-\mathrm{MS}$

46. Nasr-El-Din H.A., Arnaout I.H., Chesson J.B., Cawiezel K. Novel Technique for Improved CT Access and Stimulation in an Extended-Reach Well. SPE 94044, 2005. DOI: 10.2118/94044-MS

47. Glasbergen G., Buijse M. Improved Acid Diversion Design Using a Placement Simulator. SPE 102412-MS, 2006. DOI: 10.2118/102412-MS

48. Nasr-El-Din H.A., Taylor K.C., Al-Hajii H.H. Propagation of Cross-Linkers Used in In-Situ Gelled Acids in Carbonate Reservoirs. SPE 75257, 2002. DOI: 10.2118/75257-MS

49. Loginov B.G., Malyshev L.G., Garifullin Sh.S. Rukovodstvo po kislotnym obrabotkam skvazhin [Acid Wells Guide]. Moscow: Nedra, 1966,219 p.

50. Suchkov B.M. Soliano-kislotnye obrabotki skvazhin v dinamicheskom rezhime [Hydrochloric acid treatment of wells in dynamic mode]. Neftianoe khoziaistvo, 1987, no. 6 , pp. $52-56$

51. Ibragimov G.Z., Khisamutdinov N.I. Spravochnoe posobie po primeneniiu khimicheskikh reagentov v dobyche nefti [A reference manual for the use of chemicals in oil production]. Moscow: Nedra, 1983, $312 \mathrm{p}$

52. Arbuzov V.N. Ekspluatatsiia neftianykh i gazovykh skvazhin [Operation of oil and gas wells]. Tomsk: Tomskii politekhnicheskii universitet, 2011, part. 1, 200 p.

53. Magee J., Buijse M.A., Pongratz R. Method for Effective Fluid Diversion When Performing a Matrix Acid Stimulation in Carbonate Formation. SPE 37736, 1997, March, 17-20. DOI: 10.2118/37736-MS

54. Al-Mutawa M., Al-Anzi E., Jemmali M., Samuel M. Field Cases of a Zero Damaging Stimulation and Diversion Fluid from the Carbonate Formations in North Kuwait. SPE 80225, 2003, February, 5-8. DOI: 10.2118/80225-MS

55. Olson K.E., Olsen E., Haidar S., Boulatsel A., Brekke K. Valhall Field: Horizontal Well Stimulations "Acid vs. Proppant" and Best Practices for Fracture Optimization. SPE 84392, 2003, October. DOI: 10.2118/84392-MS

56. Diaz N.J., Bell M.R.G., Hardesty J.T., Hill A.D., Nasr-EI-Din H.A. An Evaluation of the Impact of Reactive Perforating Charges on Acid Wormholing in Carbonates. SPE 138434, 2010. DOI: 10.2118/138434-MS

57. Wang Xugang, Zou Honglan, Zheng Xingquan, Zhang Fuxiang, Fan Yonghong, Cheng Xingsheng, Zhang Rusheng. Optimization of Acid Fracturing to Improve Heavy Oil Production in Naturally Fractured Carbonates. SPE 80897, 2003. DOI: 10.2118/80897-MS

58. Pournik M., Mahmoud M., Nasr-El-Din H.A. A Novel Application of Closed-Fracture Acidizing. SPE 124874, 2011. DOI: 10.2118/124874-MS

59. Reese J.L., Britt L.K., Jones J.R. Selecting Economic Refracturing Candidates. SPE 28490, 1994. DOI: 10.2118/28490-MS

60. Parrot D.I., Long M.G. A Case History of Massive Hydraulic Refracturing in the Tight Muddy "J" Formation. SPE 7936, 1979. DOI: 10.2118/7936-MS

61. Vadetskii Iu.V., Obmoryshev K.M., Okun' B.I. Ispytanie treshchinnykh kollektorov v protsesse bureniia [Testing fractured reservoirs while drilling]. Moscow: Nedra, 1976, 157 p. 62. Mahmoud M.A., Nasr-El-Din H.A., De Wolf C.A., LePage J.N. Optimum Injection Rate of A New Chelate that Can Be Used to Stimulate Carbonate Reservoirs. SPE 133497, 2011. DOI: 10.2118/133497-MS

63. Mahmoud M.A., Nasr-El-Din H.A., De Wolf C.A., LePage J.N. Stimulation of Carbonate Reservoirs Using GLDA (Chelating Agent) Solutions. SPE 132286, 2010. DOI: 10.2118/132286-MS 64. Hoefner M.L., Fogler H.S. Pore Evolution and Channel Formation during Flow and Reaction in Porous Media. AIChE J, 1988, vol. 34, no. 1, pp. 45-54. DOI: 10.1002/aic.690340107 65. Kalfayan L. Production Enhancement with Acid Stimulation. 2 ed. Tulsa Oklahoma: PennWell Corporation, 2008,270 p.

66. Fredd C.N., Fogler H.S. The Influence of Chelating Agents on the Kinetics of Calcite Dissolution. J. Colloid Interface Sci., 1998, August, no. 204(1), pp. 187-197. DOI: 10.1006/jcis.1998.5535

66. Fredd C.N., Fogler H.S. The Influence of Chelating Agents on the Kinetics of Calcite Dissolution. J. Colloid Interface Sci, 1998, August, no. 204(1), pp. 187-197. DOI: 10.1006/jcis.1998.5535
67. Fredd C.N., Fogler H.S. The Kinetics of Calcite Dissolution in Acetic Acid Solutions. Chem. Eng. Sci., 1998, October, no. 53(22), pp. 3863-3874. DOI: 10.1016/S0009-2509(98)00192-4

68. Fredd C.N., Fogler H.S. Alternative Stimulation Fluids and Their Impact on Carbonate Acidizing. SPE J., 1998, no. 813(1), 34 p. DOI: 10.2118/31074-MS

69. Abu-Syed I.S., Shuchart C.E., Gong M. Well Stimulation for Thick Carbonate Reservoirs. IPTC 10647, 2005. DOI: 10.2523/IPTC-10647-MS

70. Al-Ghamdi A.H., Nasr-El-Din H.A., Al-Qahtani A.A., Samuel M.M. Impact of Acid Additives on the Rheological Properties of Viscoelastic Surfactants and Their Influence on Field Application. SPE 89418, 2004. DOI: 10.2118/89418-PA

\section{Библиографический список}

1. Тенденции в обработке матрицы / К. Кроуи, Ж. Масмонтейл, Э. Тоубул, Т. Рон // Нефтяное обозрение. - 1996. - № 10. - С. $20-37$.

2. Грей Ф. Добыча нефти / пер. с англ. З.П. Свитанько. - М.: Олимп-Бизнес, 2001. - 416 с.

3. Fransh H. Increasing the Flow of Oil Wells. - US 556669. - 1896.

4. Rae Ph., di Lullo G. Matrix Acid Stimulation // SPE European Formation Damage Conference. - The Hague, The Netherlands, 13-14 May, 2003. Paper SPE 82260. - 2003. DOI: 10.2118/82260-MS 5. Комплексный подход к увеличению эффективности кислотных обработок скважин в карбонатных коллекторах / А.Г. Телин, Т.А. Исмагилов, Н.3. Ахметов, В.В. Смыков, Н.И. Хисамутдинов // Нефтяное хозяйство. - 2001. - № 8. - С. 69-74.

6. Патент № 7603261 США, МПК G 06 F 17/50, Е 21 в 36/02. Method for Predicting Acid Placement in Carbonate Reservoirs / Philippe Tardy; заявитель и патентообладатель Schlumberger Technology Corporation. - № US 2008/0015832 A1; заявл. 29.11.06 ; опубл. 13.10.09. - 31 с.

7. Патент № 7774183 США, МПК G 06 F 7/48. Flow of Self-Diverting Acids in Carbonate Reservoirs / Рhilippe Tardy, Bruno Lecerf; заявитель и патентообладатель Schlumberger Technology Corporation. - № US 2008/0015831 А1; заявл. 11.07.06 ; опубл. 10.08.10. - 20 c.

8. Патент № 7853440 США, МПК G 06 F 7/48. Method for Large-Scale Modeling and Simulation of Carbonate Wells Stimulation / Charles Edouard Cohen, Didier Ding, Brigitte Bazin, Nichel Quintard ; заявитель и патентообладатель Institut Francais du Petrole. - № US 2007/0244681 A1; заявл. 09.03.07 ; опубл. 14.12.10. - 15 с. 9. Патент № 7666821 США, МПК С 09 К 8/60. Self-Diverting Pre-Flush Acid for Sandstone / Diankui Fu; заявитель и патентообладатель Schlumberger Tесhnology Corporation. - № US 2004/0009880 А1; заявл. 20.02.03 ; опубл. 23.02.10. - 26 с.

10. Патент № 7770644 США, МПК Е 21 В 43/16. Self Diverting Matrix Acid / Diankui Fu, Mohan Panga, Slaheddine Kefi, Marieliz Garcia-Lopez de Victoria; заявитель и патентообладатель Schlumberger Technology Corporation. - № US 2007/0256835 A1; заявл. 27.06.07; опубл. 10.08.10. - 10 с.

и патентообладатель Schlumberger Technology Corporation. - № US 2007/0256835 A1, заявл. 27.06.07; опубл. 10.08.10. - 10 c. M. Samuel, Francois M. Auzerais ; заявитель и патентообладатель Schlumberger Technology Corporation. - № US 2010/0056405 A1; заявл. 21.08.09; опубл. 08.03.11. - 9 с. 12. Глущенко В.Н., Пташко О.А., Харисов Р.Я. Кислотные обработки: составы, механизмы реакций, дизайн. - Уфа : АН РБ, Гилем, $2010 .-388$ с.

13. Факторы, влияющие на эффективность кислотной стимуляции скважин в карбонатных коллекторах / Р.Я. Харисов, А.Р. Шарифуллин, А.Г. Телин, А.Г. Загуренко // Научно-технический вестник ОАО «НК «Роснефть». - 2007. - № 1. - С. 18-24.

14. Pongratz R., Kontarev R., Robertson B. Optimizing Matrix Acid Treatments in a Multilayered Reservoir in Russia by Applying Different Diversion Techniques // SPE 94485. - 2005. - May, 27. DOI: 10.2118/94485-MS

15. Исследования кислотного воздействия с применением потокоотклонителей на карбонатные коллекторы месторождения им. Р. Требса / С.А. Вахрушев, А.Е. Фоломеев, Ю.А. Котенев, Р.М. Набиуллин // Нефтяное хозяйство. - 2016. - № 4. - С. 112-117.

16. Emulsified Acid Enhances Well Production in HighTemperature Carbonate Formations / R.C. Navarrete, B.A. Holms, S.B. McConnell, D.E. Linton // SPE 50612. 1998. - October, 20-22. DOI: 10.2118/50612-MS

17. Field Application of Emulsified Acid-Based System to Stimulate Deep, Sour Gas Reservoirs in Saudi Arabia / H.A. Nasr-El-Din, J.R. Solares, S.H. Al-Mutairi, M.D. Mahoney // SPE 71693. - 2001. - September, 30-October, 03. DOI: 10.2118/71693-MS

18. Saxon A., Chariag B., Reda Abdel Rahman M. An Effective Matrix Diversion Technique for Carbonate Formations // SPE 37734. - 1997. - March, 15-18. DOI: 10.2118/37734-MS 19. Kalfayan L.J., Martin A.N. The Art and Practice of Acid Placement and Diversion: History, Present State, and Future // SPE 124141. - 2009. DOI: 10.2118/124141-MS 20. Gdanski R. Recent Advances in Carbonate Stimulation // IPTC 10693. - 2005. - November, 21-23. DOI: 10.2523/IPTC-10693-MS

21. Williams B.B., Gidley J.L., Schechter R.S. Acidizing Fundamentals // Soc. Petrol. Eng. of AIME. - New York, Dallas, 1979. - Ch. 10.

22. Economides M.J., Nolte K.G. Acid Fracture Propagation and Production, in Reservoir Stimulation. - Prentice Hall, Englewood Cliffs, NJ, $1989 .-$ Ch. 18.

23. Economides M.J., Nolte K.G. Reservoir Stimulation. - 3 Ed. - John Willey \& Sons, Ltd, New York, 2000.

24. Экономидес М., Нолте К. Повышение продуктивности нефтегазовых коллекторов: в 2 т. - М. - Ижевск: Институт компьютерных исследований, 2011. - Т. 1. 676 c.; T. 2. -674 c.

25. Economides M.J. Petroleum Production Systems / M.J. Economides, A.D. Hill, C. Ehlig-Economides. - Upper Saddle River, NJ 07458, 1993. - 611 p. 
26. Экономидес М., Олини Р., Валько П. Унифицированный дизайн гидроразрыва пласта: от теории к практике: пер. с англ. А. Корнилов, И. Вафин; ОАО «НК «Роснефть». - М.: Ин-т компьютерных исследований, 2007. - 236 с.

27. Успешный кислотный гидроразрыв пласта (ГРП) в неблагоприятных условиях Харьягинского месторождения: полученный опыт и комплексная оценка работ / А. Пуатрено, П. Ферран, П. Пужет, Ж. Мэньер // SPE 102475. - 2006. DOI: 10.2118/102475-MS

28. Патент № 6772847 США, МПК Е 21 В 7/04, Е 21 В 7/18. Chemically Enhanced Drilling Methods / Rae Philip J., Di Lullo Arias, Gino F., Portman, Lance N.; заявитель и патентообладатель BJ Services Company. - № US 2003/0164252 A1; заявл. 26.02.02 ; опубл. 10.08.04. - 11 с.

29. Rae Ph., di Lullo G. Chemically-Enhanced Drilling With Coiled Tubing in Carbonate Reservoirs // SPE 67830. DOI: 10.2118/67830-MS

30. Portman L., Rae Ph., Munir A. Full-Scale Tests Prove it Practical to «Drill» Holes with Coiled Tubing Using Only Acid; No Motors, No Bits // SPE 74824 . - 2002. DOI: 10.2118/74824-MS

31. Global Application of Coiled-Tubing Acid Tunneling Yields Effective Carbonate Stimulation / F.O. Stanley, L.N. Portman, J.D. Diaz, R.L. Darmawan, J.P. Strasburg, J.S. Clark, M.S. Navarro // SPE 135604. - 2010. DOI: 10.2118/135604-MS

32. Moss P., Portman Rae L., di Lullo G. Nature Had It Right After All! Constructing a "Plant Root" - Like Drainage System with Multiple Branches and Uninhibited Communication with Pores and Natural Fractures // SPE 103333. - 2006. DOI: 10.2118/103333-MS

33. Successful Offshore Application of Acid Tunneling Technology: Overcoming the Difficulties of High Depths, Temperatures, and Deviations / L.A.A. Perex, J.D. Diaz, M. Navarro, P. Moss, J. Curtis // SPE 113855. - 2008. DOI: 10.2118/113855-MS

34. Successful Implementation of Coiled-Tubing Acid Tunneling Gives Operator a Viable Alternative to Conventional Stimulation Techniques in Carbonate Reservoirs / J.D. Diaz, V. Espina, M. Guerrero, O. Colmenares, P. Moss // SPE 107084. - 2007. DOI: 10.2118/107084-MS

35. Akhkubekov A.E., Vasilyev V.N. Acid Tunneling Technology: Application Potential in Timan-Pechora Carbonates // SPE 135989. - 2010. DOI: 10.2118/135989-MS

36. Strasburg J., Clark J. Acid Tunneling Stimulation in Oklahoma Limestone Using Coiled Tubing // SPE 120772. - 2009. DOI: 10.2118/120772-MS

37. Овнатанов Г.Т. Вскрытие и обработка пласта. - М.: Недра, 1970. - 312 с

38. Fredrickson S.E. Stimulating Carbonate Formations Using a Closed Fracture Acidizing Technique // SPE 14654. - 1986. DOI: 10.2118/14654-MS

39. Патент № 3768564 США, МПК Е 21 в 43/27. Method of Fracture Acidizing Formation / S.E. Frederickson, J.А. Кпох; заявитель и патентообладатель Наlliburton Company. - 137625; заявл. 26.04.71; опубл. 30.10.73. - 5 с.

40. Патент № 3842911 США, МПК Е 21 в 43/27, Е 21 в 43/26. Method of Fracture Acidizing a Well Formation / Кnox J.A., Frederickson S. Е; заявитель и патентообладатель Halliburton Company. - № 349909; заявл. 09.04.73; опубл. 22.10.74. - 4 с.

41. Sollman M.Y., Hunt J.L., Daneshi T. Well-Test Analysis Following a Closed-Fracture Acidizing Treatment // SPE 17972. - 1990. DOI: 10.2118/17972-PA

42. Field and Laboratory Experience in Closed Fracture Acidizing the Lisburne Field, Prudhoe Bay, Alaska / K.M. Bartko, M.W. Conway, T.E. Krawietz, R.B. Marquez, R.G.M. Oba // SPE 24855. - 1992. DOI: 10.2118/24855-MS

43. Paccaloni G., Tambini M. Advances in Matrix Stimulation Technology // JPT. - 1993. - № 43 (3). - P. 256-263. DOI: 10.2118/20623-PA

44. Bhalla K. Coiled Tubing Extended Reach Technology // SPE 30404. - 1995. DOI: 10.2118/30404-MS

45. A Novel Technique to Acidize Horizontal Wells with Extended Reach / H.A. Nasr-El-Din, N.S. Al-Habib, M. Jemmali, A. Lahmadi, M. Samuel // SPE 90385. - 2004. DOI: $10.2118 / 90385-\mathrm{MS}$

46. Novel Technique for Improved CT Access and Stimulation in an Extended-Reach Well / H.A. Nasr-El-Din, I.H. Arnaout, J.B. Chesson, K. Cawiezel // SPE 94044. 2005. DOI: $10.2118 / 94044-\mathrm{MS}$

47. Glasbergen G., Buijse M. Improved Acid Diversion Design Using a Placement Simulator // SPE 102412-MS. - 2006. DOI: 10.2118/102412-MS

48. Nasr-El-Din H.A., Taylor K.C., Al-Hajiji H.H. Propagation of Cross-Linkers Used in In-Situ Gelled Acids in Carbonate Reservoirs // SPE 75257. - 2002. DOI: 10.2118/75257-MS

49. Логинов Б.Г., Малышев Л.Г., Гарифуллин Ш.С. Руководство по кислотным обработкам скважин. - М.: Недра, 1966. - 219 с.

50. Сучков Б.М. Соляно-кислотные обработки скважин в динамическом режиме // Нефтяное хозяйство. - 1987. - № 6. - С. 52-56.

51. Ибрагимов Г.З., Хисамутдинов Н.И. Справочное пособие по применению химических реагентов в добыче нефти. - М.: Недра, 1983. - 312 с.

52. Арбузов В.Н. Эксплуатация нефтяных и газовых скважин. - Томск : Изд-во ТПУ, 2011. - Ч. 1. - 200 с.

53. Magee J., Buijse M.A., Pongratz R. Method for Effective Fluid Diversion When Performing a Matrix Acid Stimulation in Carbonate Formation // SPE 37736. - 1997. March, 17-20. DOI: 10.2118/37736-MS

54. Field Cases of a Zero Damaging Stimulation and Diversion Fluid from the Carbonate Formations in North Kuwait / M. Al-Mutawa, E. Al-Anzi, M. Jemmali, M. Samuel // SPE 80225. - 2003. - February, 5-8. DOI: 10.2118/80225-MS

55. Valhall Field: Horizontal Well Stimulations «Acid vs. Proppant» and Best Practices for Fracture Optimization / K.E. Olson, E. Olsen, S. Haidar, A. Boulatsel, K. Brekke // SPE 84392. - 2003, October. DOI: 10.2118/84392-MS

56. An Evaluation of the Impact of Reactive Perforating Charges on Acid Wormholing in Carbonates / N.J. Diaz, M.R.G. Bell, J.T. Hardesty, A.D. Hill, H.A. Nasr-EI-Din // SPE 138434. - 2010. DOI: 10.2118/138434-MS

57. Optimization of Acid Fracturing to Improve Heavy Oil Production in Naturally Fractured Carbonates / Xugang Wang, Honglan Zou, Xingquan Zheng, Fuxiang Zhang, Yonghong Fan, Xingsheng Cheng, Rusheng Zhang // SPE 80897. - 2003. DOI: 10.2118/80897-MS

58. Pournik M., Mahmoud M., Nasr-El-Din H.A. A Novel Application of Closed-Fracture Acidizing // SPE 124874. - 2011. DOI: 10.2118/124874-MS

58. Pournik M., Mahmoud M., Nasr-El-Din H.A. A Novel Application of Closed-Fracture Acidizing // SPE 124874. - 2011. DOI: 10.21

60. Parrot D.I., Long M.G. A Case History of Massive Hydraulic Refracturing in the Tight Muddy «J» Formation // SPE 7936. - 1979. DOI: 10.2118/7936-MS

61. Вадецкий Ю.В., Обморышев К.М., Окунь Б.И. Испытание трещинных коллекторов в процессе бурения. - М.: Недра, 1976. - 157 с.

62. Optimum Injection Rate of A New Chelate that Can Be Used to Stimulate Carbonate Reservoirs / M.A. Mahmoud, H.A. Nasr-El-Din, C.A. De Wolf, J.N. LePage // SPE 133497. - 2011. DOI: 10.2118/133497-MS

63. Stimulation of Carbonate Reservoirs Using GLDA (Chelating Agent) Solutions / M.A. Mahmoud, H.A. Nasr-El-Din, C.A. De Wolf, J.N. LePage // SPE 132286. - 2010. DOI: $10.2118 / 132286-\mathrm{MS}$

64. Hoefner M.L., Fogler H.S. Pore Evolution and Channel Formation during Flow and Reaction in Porous Media // AIChE J. - 1988. - Vol. 34, № 1. - P. 45-54.

64. Hoefner M.L., Fogler H.S. Pore Evolution and Channel Formation during Flow and Reaction in Porous Media // AIChE J.
DOI: 10.1002/aic.690340107

65. Kalfayan L. Production Enhancement with Acid Stimulation. - 2 ed. - Tulsa Oklahoma: PennWell Corporation, 2008. - 270 p.

66. Fredd C.N., Fogler H.S. The Influence of Chelating Agents on the Kinetics of Calcite Dissolution // J. Colloid Interface Sci. - 1998. - August. - № 204 (1). P. 187-197. DOI: $10.1006 /$ jcis. 1998.5535

67. Fredd C.N., Fogler H.S. The Kinetics of Calcite Dissolution in Acetic Acid Solutions // Chem. Eng. Sci. - 1998. - October. - № 53 (22). - P. $3863-3874$. DOI: 10.1016/S0009-2509(98)00192-4

68. Fredd C.N., Fogler H.S. Alternative Stimulation Fluids and Their Impact on Carbonate Acidizing // SPE J. - 1998. - № 813 (1). - P. 34. DOI: 10.2118/31074-MS

69. Abu-Syed I.S., Shuchart C.E., Gong M. Well Stimulation for Thick Carbonate Reservoirs // IPTC 10647. - 2005. DOI: 10.2523/IPTC-10647-MS

70. Impact of Acid Additives on the Rheological Properties of Viscoelastic Surfactants and Their Influence on Field Application / A.H. Al-Ghamdi, H.A. Nasr-El-Din, Al-Qahtani, A.A. Abdulqader, M. Samuel // SPE 89418. - 2004. DOI: 10.2118/89418-PA 